\title{
COMPARISON OF SEROLOGY, ANTIGENEMIA ASSAY AND THE POLYMERASE CHAIN REACTION FOR MONITORING ACTIVE CYTOMEGALOVIRUS INFECTIONS IN HEMATOPOIETIC STEM CELL TRANSPLANTATION PATIENTS
}

Sandra Helena Alves BONON(1), Cláudio Lúcio ROSSI(2), Cármino Antonio DE SOUZA(3), Afonso Celso VIGORITO(3) \& Sandra Cecília Botelho COSTA(1)

\begin{abstract}
SUMMARY
Forty-six allogeneic hematopoietic stem cell transplantation (HSCT) patients were monitored for the presence of CMV antibodies, CMV-DNA and CMV antigens after transplantation. Immunoenzymatic serological tests were used to detect IgM and the increase in CMV IgG antibodies ( $\uparrow \operatorname{IgG}$ ), a nested polymerase chain reaction (N-PCR) was used to detect CMV-DNA, and an antigenemia assay (AGM) was used to detect CMV antigens. The presence of CMV-IgM and/or CMV- $\uparrow$ IgG antibodies was detected in $12 / 46$ (26.1\%) patients, with a median time between HSCT and the detection of positive serology of 81.5 days. A positive AGM was detected in 24/46 (52.2\%) patients, with a median time between HSCT and antigen detection of 62 days. Two or more consecutive positive N-PCR results were detected in 32/46 (69.5\%) patients, with a median time between HSCT and the first positive PCR of 50.5 days. These results confirmed that AGM and mainly PCR are superior to serology for the early diagnosis of CMV infection. Six patients had CMV-IgM and/or CMV- IgG with a negative AGM (five cases) or N-PCR assay (one case). In five of these cases the serological markers were detected during the first 100 days after HSCT, the period of highest risk. These findings support the idea that serology may be useful for monitoring CMV infections in HSCT patients, especially when PCR is unavailable.
\end{abstract}

KEYWORDS: Cytomegalovirus; Serology; Nested-PCR; Antigenemia; Hematopoietic stem cell transplantation.

\section{INTRODUCTION}

Several reports have shown that cytomegalovirus (CMV) infection after hematopoietic stem cell transplantation (HSCT) is associated with significant morbidity, decreased patient survival, and considerable cost to health-care systems ${ }^{10,12}$. In recent years, there have been important advances in antiviral prophylactic strategies and in the development of sensitive diagnostic techniques for monitoring recipients of bone marrow transplantation $(\mathrm{BMT})^{2}$. Newer methods, such as early CMV pp65 antigenemia assay and CMV-DNA amplification, can diagnose CMV infection in its very early period ${ }^{3,14}$. Serological tests for detecting specific IgM antibodies and/or a significant increase in specific IgG concentrations are valuable diagnostic tools in BMT recipients with primary or recurrent CMV infection ${ }^{4,6}$.

In this study, we compare the results obtained with a nested polymerase chain reaction (N-PCR), an antigenemia assay (AGM) and serology (detection of CMV-IgM antibodies and a significant increase in CMVIgG concentrations) obtained during the first four months after HSCT.

\section{MATERIAL AND METHODS}

Patients: Forty-six myeloablative HSCT recipients with HLA identical siblings were selected at the BMT Unit of the University hospital of the State University of Campinas (UNICAMP). All of the patients (39 adults and seven children) had hematological malignancies. The conditioning regimens and acute graft versus host disease (GVHD) prophylaxis were selected based on ongoing protocols at the university hospital. All patients received GVHD prophylaxis with cyclosporine (CSP) and methotrexate (MTX) and received ganciclovir (GCV) universal prophylaxis at a dose of $5 \mathrm{mg} / \mathrm{kg}$ i.v., once daily, three days per week, from the engraftment until day 75 after transplantation. Patients were followed from day 0 to day 150 after transplant. The AGM and N-PCR were done weekly, whereas serology was performed once a month. This study was approved by the Ethics Committee of the Faculty of Medical Sciences, UNICAMP, and was done in accordance with the resolutions of the Brazilian National Ethics Committee.

Diagnostic techniques: The CMV-AGM assay was done as previously described $^{16}$, with some modifications ${ }^{5,11}$. Briefly, EDTAtreated blood samples were fractionated by dextran sedimentation followed by erythrocyte lysis. The granulocytes were then centrifuged to prepare Cytospin slides ( $3 \times 10^{5}$ granulocytes per slide). The slides were air-dried and fixed with formaldehyde, prior to immunostaining with monoclonal antibodies $\mathrm{C} 10$ and $\mathrm{C} 11$ (Clonab CMV; Biotest,

(1) Department of Internal Medicine, Faculty of Medical Sciences, State University of Campinas (UNICAMP), Campinas, SP, Brazil.

(2) Department of Clinical Pathology, Faculty of Medical Sciences, UNICAMP, Campinas, SP, Brazil.

(3) Bone Marrow Transplant Unit, Hemocenter, UNICAMP, Campinas, SP, Brazil.

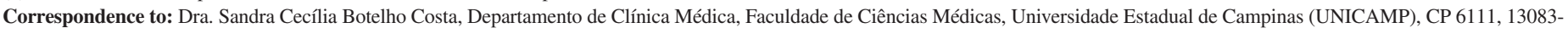
970 Campinas, São Paulo, Brasil. Tel: +55-19-3521-7734; Fax: +55-19-3289-4107. E-mail: costa@ fcm.unicamp.br 


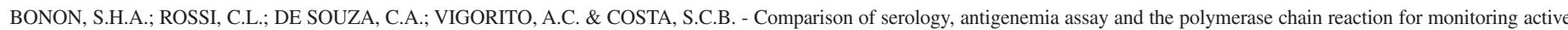
cytomegalovirus infections in hematopoietic stem cell transplantation patients. Rev. Inst. Med. trop. S. Paulo, 48(5): 275-278, 2006.

Dreieich, Germany), and then reacted with peroxidase-labeled antimouse conjugate (HRP, Biotest, Dreieich, Germany). CMV-DNA in blood specimens was detected by nested-PCR using primers described by DEMMLER et al. ${ }^{3}$ and SHIBATA et al. ${ }^{14}$. Briefly, leukocytes remaining from the CMV-AGM assay were lysed and the DNA was precipitated. The primers were selected from the MIE region of CMVAD169. The size of the PCR amplification products was 159 base pairs. The same protocol was used to amplify the human $\beta$-globin gene sequence to assess the quality of the extracted DNA. Studies on the sensitivity of the N-PCR showed that five copies of target DNA could be detected ${ }^{15}$. Anti-CMV IgM and IgG antibodies were determined on a Vidas System using commercial kits from Biolab-Mérieux, according to the manufacturer's instructions. A fourfold or greater increase in IgG concentrations (CMV- $\uparrow \mathrm{IgG})$ was considered significant.

Definitions: Active CMV infection was defined based on one or both of the following criteria: 1) one or more positive cells in the AGM assay, 2) two or more consecutive positive N-PCR results. For the diagnosis of CMV disease, the active infection had to be accompanied by clinical symptoms and histopathology identifying $\mathrm{CMV}^{2}$.

Ganciclovir prophylaxis: CMV-seronegative patients and donors and patients with aplastic anemia did not receive ganciclovir prophylaxis. This strategy was based on an established institutional protocol. When neutropenia occurred, granulocyte colony-stimulating factor (G-CSF) was administered until the absolute neutrophil count was $>500$ cells $/ \mu \mathrm{L}$.

Statistical analysis: The sensitivity, specificity, positive and negative predictive values and diagnostic accuracy were determined using S-Plus software (Math Soft Inc.).

\section{RESULTS}

Table 1 shows the frequencies of positive PCR and AGM assays and the detection of IgM and/or $\uparrow \operatorname{IgG}$, as well as the median times between HSCT and the positive results for these assays in the different $\mathrm{CMV}$ donor/recipient combinations.

Positive PCR and AGM assays and the detection of CMV-IgM or CMV- $\uparrow$ IgG were observed in 32 (69.5\%), 24 (52.2\%) and $12(26.1 \%)$ of the 46 patients monitored, respectively.
The median times between HSCT and positive PCR and AGM assays and the detection of CMV-IgM or CMV- $\uparrow$ IgG were 50.5 (range 0-143 days), 62 (range 17-133 days), and 81.5 days (range 33-131 days), respectively.

Thirteen patients (11 in the $\mathrm{D}+/ \mathrm{R}+$ combination, two in the $\mathrm{D}+/ \mathrm{R}$ combination) had positive PCR and negative AGM results, whereas 21 patients ( 15 in the $\mathrm{D}+/ \mathrm{R}+$ combination, four in the $\mathrm{D}+/ \mathrm{R}$ - combination and two in the $\mathrm{D}-/ \mathrm{R}+$ combination) had a positive $\mathrm{PCR}$ without detection of CMV-IgM or CMV- $\uparrow \operatorname{IgG}$. Five patients (four in the D+/R+ combination and one in the $\mathrm{D}-/ \mathrm{R}+$ combination) had a positive AGM assay and negative PCR, whereas 17 patients (12 in the $\mathrm{D}+/ \mathrm{R}+$ combination, two in the D+/R- combination and three in the D-/R+ combination) had a positive AGM assay without detection of CMVIgM or CMV- $\uparrow$ IgG.

In the $\mathrm{D}+/ \mathrm{R}+$ combination, one patient had $\mathrm{CMV}-\uparrow \mathrm{IgG}$, a negative PCR and a positive AGM assay, and five patients had CMV-IgM or CMV- $\uparrow$ IgG, a positive PCR and a negative AGM.

Two patients in the $\mathrm{D}+/ \mathrm{R}+$ combination showed CMV-related gastrointestinal symptoms after HSCT and were successfully treated with ganciclovir (GCV). In one of these patients, the PCR and AGM assays became positive at the same time as the onset appearance of the clinical symptoms, 33 days after HSCT, whereas CMV-IgM was detected 49 days later. In the other patient, the PCR and AGM assays became positive 55 days after HSCT and 26 days before the onset of the clinical symptoms; CMV-IgM was detected 43 days after the PCR and AGM assays became positive.

Using N-PCR as the reference standard, the AGM assay showed $59.4 \%$ sensitivity and $64.3 \%$ specificity (positive predictive value $=$ $79.2 \%$; negative predictive value $=64.3 \%$; diagnostic accuracy $=$ $60.9 \%$ ), whereas the sensitivity and specificity of the serology were $34.4 \%$ and $92.9 \%$, respectively (positive predictive value $=91.7 \%$; negative predictive value $=92.8 \%$; diagnostic accuracy $=52.2 \%$ )

\section{DISCUSSION}

CMV disease continues to be a major source of patient morbidity and mortality after $\mathrm{HSCT}^{1,8,10}$. After infection, CMV remains latent in several cell types and may eventually produce disease. Reactivation of

Table 1

PCR, AGM and serological results for HSCT recipients

\begin{tabular}{|c|c|c|c|c|c|c|c|}
\hline $\begin{array}{l}\text { CMV } \\
\text { serostatus }\end{array}$ & $\begin{array}{c}\mathrm{N}-\mathrm{PCR}+ \\
(\%)\end{array}$ & $\begin{array}{c}\text { MT for a } \\
\text { positive } \\
\text { N-PCR after } \\
\text { HSCT(range) }\end{array}$ & $\begin{array}{c}\mathrm{AGM}+ \\
(\%)\end{array}$ & $\begin{array}{c}\text { MT for a } \\
\text { positive } \\
\text { AGM after } \\
\text { HSCT (range) }\end{array}$ & $\begin{array}{c}\text { Serology }+ \\
(\%)\end{array}$ & $\begin{array}{c}\text { MT for a } \\
\text { positive } \\
\text { serology after } \\
\text { HSCT (range) }\end{array}$ & $\begin{array}{c}\text { CMV } \\
\text { disease }\end{array}$ \\
\hline $\mathrm{D}+/ \mathrm{R}+(\mathrm{n}=38)$ & 26/38 (68.4) & $39.5(0-143)$ & $19 / 38(50)$ & $61.0(17-131)$ & $12 / 38(31.5)$ & $81.5(33-131)$ & $2 / 38$ \\
\hline$D+/ R-(n=5)$ & $4 / 5(80)$ & $57(46-88)$ & $2 / 5(40)$ & $124(115-133)$ & $0 / 5$ & - & $0 / 5$ \\
\hline$D-/ R+(n=3)$ & 2/3 (66.6) & $61(54-68)$ & $3 / 3(100)$ & $91.3(61-131)$ & $0 / 3$ & - & $0 / 3$ \\
\hline Total $(n=46)$ & $32 / 46(69.5)$ & $50.5(0-143)$ & $24 / 46(52.2)$ & $62(17-133)$ & $12 / 46(26.1)$ & $81.5(33-131)$ & $2 / 46$ \\
\hline
\end{tabular}

$\mathrm{D}+=$ positive donor; $\mathrm{R}-=$ negative recipient; $\mathrm{D}-=$ negative donor; $\mathrm{R}+=$ positive recipient; $\mathrm{MT}=$ median times (days). 
a latent CMV infection may occur in periods of reduced cellular immunity, such as with AIDS, or during immunosuppressive therapies, such as those used after solid organ and bone marrow transplantation ${ }^{8}$. Since CMV infections are either asymptomatic or associated with nonspecific clinical manifestations, laboratory techniques are essential for diagnosing the viral infection. PCR and AGM are considered the most effective markers for diagnosing active CMV infection in transplant recipients ${ }^{1,2,5,9-12,14,16}$. In BMT recipients, the ability of PCR to detect active CMV infection may be better than that of $\mathrm{AGM}^{1,2}$.

The development of a cellular immune response against CMV protects the host from dissemination of the virus after reactivation ${ }^{8}$. However, CMV-specific antibodies cannot prevent virus reactivation. Nevertheless, there is evidence that antiviral antibodies have a modulatory effect on the infection and on the subsequent clinical course of CMV disease ${ }^{13}$.

In the present study, 46 myeloablative HSCT recipients with HLAidentical siblings were followed up weekly in order to evaluate the incidence of active CMV infections on the basis of CMV PCR, AGM and serology. Our results confirmed that AGM and mainly PCR are superior to serology for the early diagnosis of active CMV infection and improves the chances for implementation specific antiviral treatment. However, approximately $26 \%$ of the patients developed a humoral immune response to $\mathrm{CMV}$, and this response occurred 33 to 131 days (median $=81.5$ days) after transplantation. Six patients had CMV-IgM and/or CMV- $\uparrow$ IgG with a negative AGM (five cases) or PCR assay (one case). In five of these cases, the serological markers were detected during the first 100 days after HSCT, the period of highest risk. When compared with N-PCR as reference standard test, the serology test had predictive positive and negative values of $91.7 \%$ and $92.8 \%$, respectively.

These findings support the idea that serology may be useful for monitoring CMV infections in HSCT patients, especially when PCR is unavailable.

\section{RESUMO}

Estudo comparativo entre sorologia, antigenemia e reação em cadeia da polimerase para o monitoramento da infecção por citomegalovírus em pacientes receptores de transplantes de células progenitoras hematopoéticas

Quarenta e seis pacientes receptores de transplantes de células progenitoras hematopoéticas (TCPH) foram monitorados em relação à infecção ativa por citomegalovírus (CMV). Testes sorológicos imunoenzimáticos foram utilizados para a detecção de anticorpos $\operatorname{IgM}$ e elevação significativa das concentrações de anticorpos $\operatorname{IgG}(\uparrow \operatorname{IgG})$, nested-PCR (N-PCR) foi utilizada para a detecção de CMV-DNA e antigenemia (AGM) para a detecção de antígenos virais. A presença de CMV-IgM e/ou CMV- $\uparrow$ IgG foi detectada em 12/46 (26,1\%) pacientes, sendo o tempo mediano entre o transplante e a detecção dos marcadores sorológicos de 81,5 dias; AGM positiva foi detectada em $24 / 46(52,2 \%)$ pacientes, sendo o tempo mediano entre o transplante e a detecção de antígenos virais de 62 dias. Dois ou mais resultados positivos consecutivos de N-PCR foram detectados em 32/46 (69,5\%) pacientes, sendo o tempo mediano entre o transplante e o primeiro teste positivo de 50,5 dias. Esses resultados confirmaram que a AGM e principalmente a PCR são superiores à sorologia, com relação ao diagnóstico da infecção pelo CMV. Seis pacientes apresentaram reações CMV-IgM positivas e/ou CMV- $\uparrow$ IgG com reações negativas de AGM (cinco casos) ou N-PCR (um caso). Em cinco desses casos, os marcadores sorológicos foram detectados nos 100 primeiros dias após o transplante, considerado o período de maior risco. Esses resultados indicam que os testes sorológicos podem ser úteis no monitoramento da infecção por CMV após o transplante de células progenitoras hematopoéticas, principalmente quando a N-PCR não for disponível.

\section{REFERENCES}

1. BHATIA, J.; SHAH, B.V.; MEHTA, A.P. et al. - Comparing serology, antigenemia assay and polymerase chain reaction for the diagnosis of cytomegalovirus infection in renal transplant patients. J. Ass. Phycns. India, 52: 297-300, 2004.

2. BONON, S.H.A.; MENONI, S.M.F.; ROSSI, C.L. et al. - Surveillance of cytomegalovirus infection in haematopoietic stem cell transplantation patients. J. Infect., 50: 130137, 2005.

3. DEMMLER, G.J.; BUFFONE, G.J.; SCHIMBOR, C.M. \& MAY, R.A. - Detection of cytomegalovirus in urine from newborns by using polymerase chain reaction DNA amplification. J. infect. Dis., 158: 1177-1184, 1988.

4. ENGELHARD, D.; WEINBERG, M.; OR, R. et al. - Immunoglobulins A, G, and M to cytomegalovirus during recurrent infection in recipients of allogeneic bone marrow transplantation. J. infect. Dis., 163: 628-630, 1991.

5. HALWACHS, G.; ZACH, R.; POGGLITSCH, H. et al. - A rapid immunocytochemical assay for CMV detection in peripheral blood of organ-transplanted patients in clinical practice. Transplantation, 56: 338-342, 1993.

6. LABA, A.; KOCWIN, E. \& LANGE, A. - Serologic and cytochemical examinations for surveillance of cytomegalovirus infection and reactivation after hematopoietic cell transplantation. Pol. Arch. Med. wewnet., 103: 241-246, 2000.

7. LANDINI, M.P. \& MACH, M. - Searching for antibodies specific for human cytomegalovirus: is it diagnostically useful? when and how. Scand. J. infect. Dis., 99: 18-23, 1995.

8. LIM, J.B.; KWON, O.H.; KIM, H.S. et al. - Adoptive immunotherapy for cytomegalovirus (CMV) disease in immunocompromised patients. Yonsei med. J., 45: 18-22, 2004.

9. MORI, T.; MORI, S.; KANDA, Y. et al. - Clinical significance of cytomegalovirus (CMV) antigenemia in the prediction and diagnosis of CMV gastrointestinal disease after allogeneic hematopoietic stem cell transplantation. Bone Marrow Transplant., 33: 431-434, 2004.

10. NICHOLS, W.G. \& BOECKH, M. - Recent advances in the therapy and prevention of CMV infections. J. clin. Virol., 16: 25-40, 2000.

11. PANNUTI, C.S.; KALLAS, E.G.; MUCCIOLI, C. et al. - Cytomegalovirus antigenemia in acquired immunodeficiency syndrome patients with untreated cytomegalovirus retinitis. Amer. J. Ophthal., 122: 847-852, 1996.

12. REUSSER, P. - Challenges and options in the management of viral infections after stem cell transplantation. Support Care Cancer, 10: 197-203, 2002.

13. SCHOPPEL, K.; SCHMIDT, C.; EINSELE, H.; HEBART, H. \& MACH, M. - Kinectics of the antibody response against human cytomegalovirus-specific proteins in allogeneic bone marrow transplant recipients. J. infect. Dis., 178: 1233-1243, 1998.

14. SHIBATA, D.; MARTIN, W.J.; APPLEMAN, M.D. et al. - Detection of cytomegalovirus DNA in peripheral blood of patients infected with human immunodeficiency virus. J. infect. Dis., 158: 1185-1192, 1988 
BONON, S.H.A.; ROSSI, C.L.; DE SOUZA, C.A.; VIGORITO, A.C. \& COSTA, S.C.B. - Comparison of serology, antigenemia assay and the polymerase chain reaction for monitoring active cytomegalovirus infections in hematopoietic stem cell transplantation patients. Rev. Inst. Med. trop. S. Paulo, 48(5): 275-278, 2006.

15. TOKIMATSU, I.; TASHIRO, T. \& NASU, M. - Early diagnosis and monitoring of human cytomegalovirus pneumonia in patients with adult T-cell leukemia by DNA amplification in serum. Chest, 107: 1024-1027, 1995.
16. VAN DER BIJ, W.; SCHIRM, J.; TORENSMA, R. et al. - Comparison between viremia and antigenemia for detection of cytomegalovirus in blood. J. clin. Microbiol., 26: 2531-2535, 1988

Received: 31 October 2005

Accepted: 30 May 2006 